\title{
The Open Source School Library Research Database: Learning without Borders
}

\author{
Jennifer L. Branch-Mueller, Wei Wei, Pauline Nicholas \\ University of Alberta, Edmonton, Canada
}

\begin{abstract}
This paper introduces the Open Source School Library Research Database (OSSLRD) and highlights the 940 items in the database. Clyde's checklist (2001) was used to identify articles, conference papers, dissertations and theses that are included in the OSSLRD. Each identified piece of research was examined and key information was gathered including author(s), date of publication, journal, participants, method(s), location of the study (if available), research methods, themes, and findings. Similar trends from previous research were confirmed: research in school librarianship is published in two major journals: School Library (Media) Research and School Libraries Worldwide. There are a small core group of researchers working in the area of school librarianship. More than half of all research is by a single author.
\end{abstract}

\section{Keywords: Open Source, Databases, Research}

\section{INTRODUCTION}

Review and analysis of research in school librarianship was close to the heart of the late L. Anne Clyde, who played a pioneering role in providing regular updates on this topic. After her untimely passing in 2005 her database of school library research was lost. To honour Dr. Clyde, a team at the University of Alberta has been working to recreate her database and make it available to all. This presentation continues the work of Asselin (2011), Clyde (2006, 2004, 2003, 2002, 2001, 1996a, 1996b) and Mardis (2011).

According to Haycock (1995), "research in school librarianship provides the foundation and direction for effective school library practice, and there is ample evidence of the impact of school library media specialists and school library media centers on students' learning, given certain conditions and criteria" (para. 1).

\section{RESEARCH QUESTION}

This research is guided by one overarching research question: What do we know about school library research? This paper will tell readers more about the development of the Open Source School Library Research Database (OSSLRD) and will present an analysis of the current contents of the database including:

- Types and quantity of research types

- Methods of data gathering

- Geographical locations

- Authorship patterns

- Key Researchers

- Themes

Clyde's checklist (2001) was used to identify articles, conference papers, dissertations and theses that are included in the OSSLRD. Each identified piece of research was examined and key information was gathered including author(s), date of publication, journal, participants, method(s), location of the study (if available), research methods, themes, and findings. 
The Open Source School Library Research Database currently has 940 entries and work is ongoing to add more. It will be freely available to anyone and researchers are able to add new items to the database.

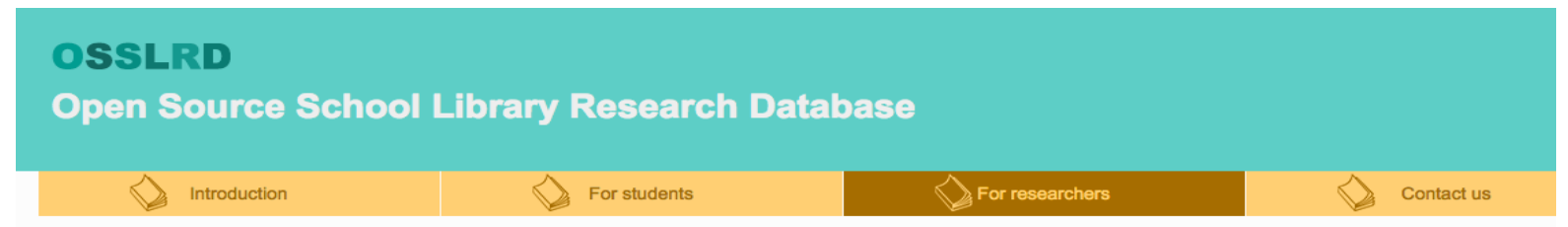

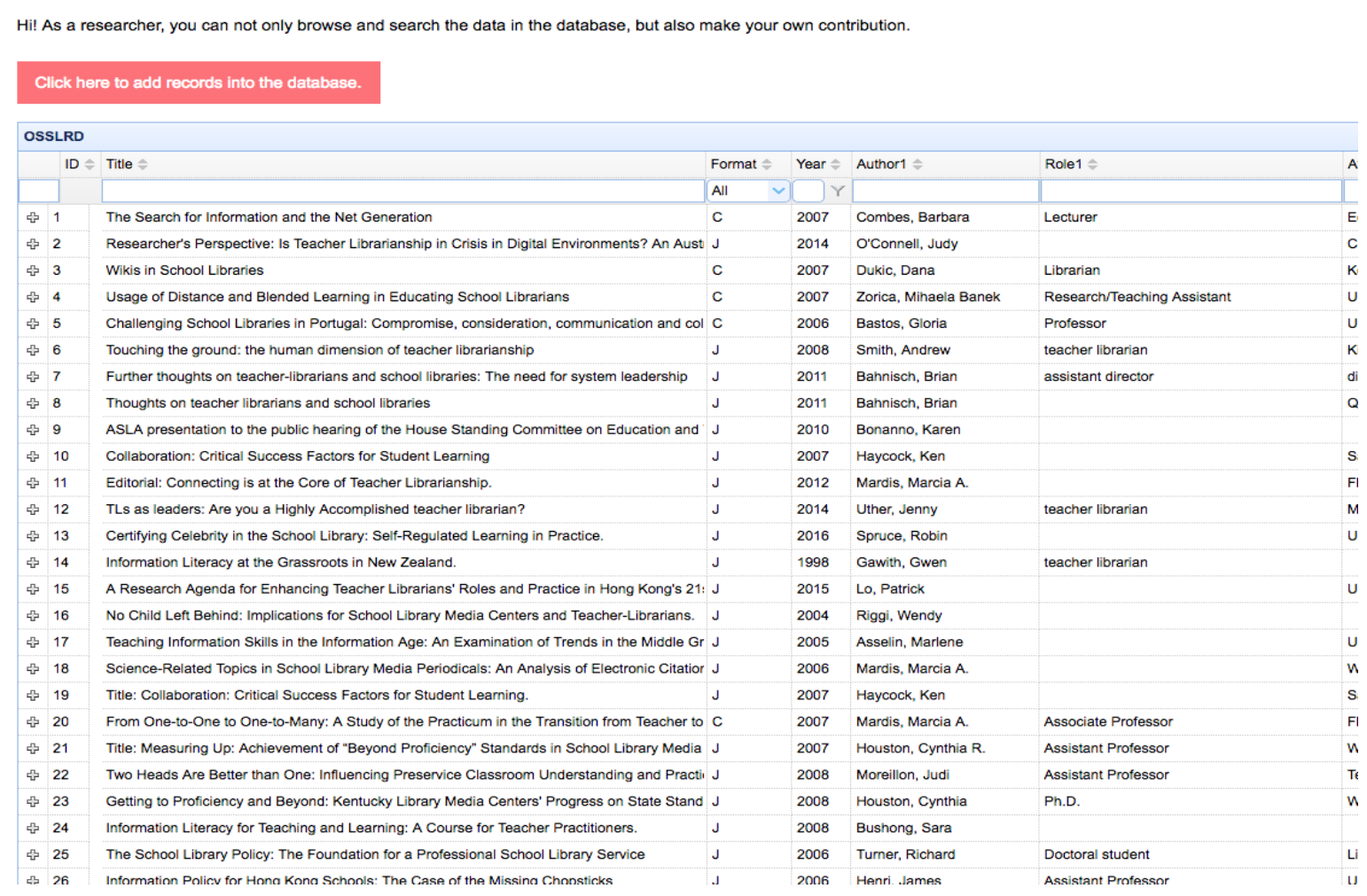

You can search by author, title, year, location, type of research item (article, conference paper, dissertation or thesis). You can also search by research method. Where possible, we have included the abstract and a link to open source articles.

\section{REVIEW OF THE LITERATURE}

As a profession interested in information and research, it is not surprising that there has been a long tradition of examining research in the field of library and information studies (LIS). Early work in this area included a study by Stroud (1982) who examined higher degree theses in LIS, Järvelin and Vakkari (1993) who examined articles in LIS research journals and Snelson and Talar (1991) who examined papers presented at LIS research-oriented conferences (Clyde, 2001, p. 70).

Studies have also been carried out to examine what makes a quality journal article, what journals produce the highest percentage of research articles, what is the content of articles based on key-word content analysis, what methods are used in current LIS research, and the percentage of research articles found in all LIS-related publications. Researchers interested in quality research journal articles tend to look to the quality of the journal itself. Clyde (2004) lists the following strategies for assessing the quality of the journal:

- citation analysis

- journal impact factor 
- number and percentage of collaborative articles

- peer-review status

- manuscript acceptance rate

- indexing of the journal

- number of external links to the journal website. (p. 1120)

Manzari (2013) examined LIS journal prestige by surveying full-time faculty in American Library Association (ALA)- accredited programs. Clyde's (2006, 2004, 2003, 2002, 2001, 1996a, 1996b) previous work clearly demonstrates that most of the research in school librarianship has been published in two major publications (1) School Libraries Worldwide and (2) School Library Research (formerly School Library Media Research). Clyde and Oberg (2004) in their study of research in School Libraries Worldwide between 1995-2003 found that about 30\% of research articles were from the USA. Canada, Australia and the UK made up another $18 \%$. There were 12 other countries represented as well as 10 articles that were international in scope. Clyde (2005) stated that "the field of school librarianship internationally has only a small core group of active researchers" (p. 6). Clyde (2005) found that there were a total 297 articles published between 1999-2003 and 43 authors published 3 or more articles.

Mardis (2011), in her examination of Research Forum Papers at International Association of School Librarianship (see Table 3) conferences between 1998-2009, found that information skills and literacy, information technology, reading and reading promotion, and education in LIS made up over $50 \%$ of the research topics.

Asselin (2011) examined the extent and nature of internationalism in IASL publications from 2002-2008 that were published in School Libraries Worldwide and in the Research Forum of IASL Conference Proceedings. She found that the United States contributed about $33 \%$ of the research and the research methods included interviews, questionnaires, surveys, case studies and observations. Examining the 307 research articles, Turcios et al. found that the most frequent research methods were survey (21\%), other (20\%), case study (13\%), content analysis (13\%), interviews (9\%), experimental research (8\%), and bibliometrics (5\%) (p. 477). Other methods included action research, classroom research, observation, focus groups, and usability (Turcios et al., 2014, p. 477).

\section{METHODOLOGY}

Along with research articles published in School Libraries Worldwide and School Library Research, the authors completed a detailed search of all databases that index school library research. They also searched for conference proceedings, dissertations and theses (indexed in Proquest Dissertations and Theses Global) reported since 1995. The Open Source School Library Research Database contains 931 items and Clyde's checklist (2001) was used to identify items that are included in this database. Items were published in English, were more than two pages long and included of some kind of statement that the work is based on research with the problem or phenomenon to be investigated well defined. Moreover, these articles, conference papers, and dissertations have a clear statement of purpose, hypotheses to be tested or a well-defined focus of inquiry, with research methods thoroughly described. A literature review or a background to the research, as well as a reference list or bibliography accompanied the publications. Finally, we examined results and conclusions that are drawn from these items.

Each identified item was entered into the database and with author(s), date of publication, journal, participants, method(s), location of the study (if available), themes, and an abstract included, when possible. Links to freely available articles are also included in the database. A breakdown of the number of articles from each publication was carried out, as well as a search to identify active researchers. We also examined patterns of authorship, and research methods used.

\section{FINDINGS}

This research seeks to understand the current state-of-the-art of research in school librarianship by examining the 940 items in the Open Source School Library Research Database from 1995 to 2016. The findings are organized by specific questions investigated in this study. 


\section{How many research journal articles in school librarianship were published between 1995-2016?}

In all, 340 articles that had a clear literature review, a research methodology, clear research questions as well as findings and a discussion section were examined from the two major journals and a number of other publications. A total of 180 articles were identified in School Libraries Worldwide, 111 were found in School Library (Media) Research and 49 articles were obtained from other journals published over the same time period. These other journals included Access, Current Studies in Librarianship, International Journal of Library and Information Services, Mousaion, Journal of Education for Library and Information Science, and Library Philosophy and Practice.

\section{How many dissertations and theses from 1995-2016?}

There are currently 398 dissertation and theses in the database. The initial search focused on school libraries, school librarianship and teacher-librarianship. The next search will also include information literacy, collection development, reading promotion in school libraries and other relevant research.

\section{How many conference papers in proceedings from 1995-2016?}

The database includes 202 conference papers. The majority of these come from the Research Forum of the International Association for School Librarianship annual conferences.

\section{What are the most frequent methods of data gathering used for research?}

The most popular choice for data gathering in the research articles was the questionnaire/survey method. A number of researchers used survey monkey and other online methods while many created their own instruments. Interviews and content analysis were very popular choices as well, followed by participant observation and focus groups. The following table provides a breakdown of the diverse methods used for doing research. It should be noted that in many cases researchers adopted more than one method to gather data, thus combining several methods to triangulate their data.

\begin{tabular}{|l|l|}
\hline \multicolumn{1}{|c|}{ Type of Data Gathering Method } & Frequency \\
\hline Survey & 322 \\
\hline Interviews & 282 \\
\hline Questionnaire & 210 \\
\hline Qualitative & 107 \\
\hline Observation & 94 \\
\hline Case Study & 88 \\
\hline Content Analysis & 81 \\
\hline Mixed Methods & 61 \\
\hline Focus Group & 50 \\
\hline Quantitative & 40 \\
\hline
\end{tabular}

Table 1: Most frequent methods of data gathering for research

Who are the key researchers in the area of school librarianship?

One hundred researchers have two or more pieces of research in the database. The most prolific researchers have five or more pieces of research between 1995-2016. 


\begin{tabular}{|l|l|}
\hline Researcher & Research Items in the Database \\
\hline Dianne Oberg & 12 \\
\hline James Herring & 11 \\
\hline Marlene Asselin & 11 \\
\hline James Henri & 11 \\
\hline Marcia Mardis & 11 \\
\hline Jennifer Branch-Mueller & 8 \\
\hline Anne Clyde & 7 \\
\hline Ross Todd & 6 \\
\hline Nancy Everhart & 6 \\
\hline Genevieve Hart & 6 \\
\hline Ken Haycock & 6 \\
\hline Carol Gordon & 5 \\
\hline Audrey Church & 5 \\
\hline Violet Harada & 5 \\
\hline
\end{tabular}

Table 2: Key Researchers

Five researchers have more than ten items in the database and nine researchers have five or more items in the database. There were another 25 researchers with three to four items in the database.

What were the authorship patterns in the items in the database?

A single author writes the vast majority of research items in the database. Removing dissertations and theses (398 items), we are left with 542 articles and conference papers. We notice then, that more than half of research items are published by a single author.

\begin{tabular}{|l|l|l|}
\hline Number of authors per research item & Frequency & Percentage \\
\hline Articles/papers with one author & 317 & 58.5 \\
\hline Articles/papers with two authors & 142 & 26.2 \\
\hline Articles/papers with three or more authors & 83 & 15.3 \\
\hline Total & $\mathbf{5 4 2}$ & $\mathbf{1 0 0}$ \\
\hline
\end{tabular}

Table 3: Authorship patterns (with dissertations and theses removed)

What were the main themes in the research papers/articles?

A more careful examination of all the items is needed before a complete classification of each item can be done. However, using information provided by the author(s), the indexer, or in the basic abstract, we can learn much about the research topics/themes. 


\begin{tabular}{|l|l|}
\hline General Research Area & Number of items in database \\
\hline Information Literacy & 113 \\
\hline Information Seeking and Needs & 59 \\
\hline Information Systems/Information Technology & 58 \\
\hline Higher Education & 37 \\
\hline Elementary, Middle and Secondary Education & 83 \\
\hline Teacher Education/LIS Education & 39 \\
\hline School Libraries & 65 \\
\hline School Administration & 208 \\
\hline Literacy, Reading and Reading Promotion & 69 \\
\hline Teacher-Librarians/School Librarians & 80 \\
\hline Professional Issues & 19 \\
\hline Principal Support & 16 \\
\hline Management/Leadership Issues & 32 \\
\hline Instruction, Curriculum, Teaching and Learning & 37 \\
\hline Table 4: Research Topics & \\
\hline
\end{tabular}

Table 4: Research Topics

\section{DISCUSSION}

This research examined the current state-of-the-art of research in school librarianship by examining research published in journals and conference proceedings as well as unpublished dissertations and theses in school librarianship published in English and within the time frame of 1995-2016. In all, 940 items were entered into the Open Source School Library Research Database. Published journal articles make up 340 of the items with 180 being published in School Libraries Worldwide, 111 published in School Library (Media) Research and 49 articles were obtained from other journals.

The most popular choice for data gathering in the research articles was the questionnaire/survey method. Interviews and observation were very popular choices as well, followed by case study, content analysis and mixed methods approaches. After excluding dissertations and theses, almost $60 \%$ of the research items had a single author while about $25 \%$ had two authors. It would be interesting to examine this over time (perhaps in 5 year chunks) to see if the single author publishing is increasing, decreasing or remaining stable. Tenure and promotion decisions may mean that more researchers are publishing alone. Research by Donaldson and Emes (2000) examined the challenges for women academics and found that "women academics collaborate more frequently than men do" (Discussion, para. 2). Since we know that the majority of researchers in school librarianship are women, perhaps authorship patterns differ from other disciplines (Crase \& Rosato, 1992)

The most prolific researchers as revealed by this review were Dianne Oberg, James Herring, Marlene Asselin, James Henri and Marcia Mardis. This review identified 39 authors who had 3 or more research items -- a far cry from the 57 documented for the 1995-1999 review (Clyde, 2001, p. 71 ) and 43 authors for the 1999-2003 (Clyde, 2005, p. 6) - especially given that this was a 20-year span. The trend 
may indicate that researchers are publishing fewer research papers in the area of school librarianship or perhaps publishing in a variety of librarianship and education areas. This may also be an indication that there are fewer school library researchers working now as compared to 20 years ago. It was impressive, however, that there were 100 researchers who had two or more items in the database.

Mardis (2011) found that information skills and literacy, information technology, reading and reading promotion, and education in LIS made up over 50\% of the research topics between 1998-2009. Reviewing the items in the database in the present review, these topics are also very popular. Each item will be reviewed in the next phase of this research study and so classification using Mardis (2011), Aharony (2011), Koufogiannakis, Slater and Crumley (2004), and Branch-Mueller and Beesoon (2015).

\section{IMPLICATIONS AND CONCLUSIONS}

This research examined the 940 items in the Open Source School Library Research Database. Similar trends from previous research were confirmed: research in school librarianship is published in two major journals -- School Library (Media) Research and School Libraries Worldwide. There are a small core group of researchers working in the area of school librarianship. More than half of all research is by a single author.

It is with great pleasure that we at the University of Alberta begin to rebuild the database of research and researchers of L. Anne Clyde. The project is ongoing and more analysis of the items is needed. However, 940 items is a great start and will allow those interested in school library research to have a starting point for locating research items. Researchers will be able to add to the database starting in the Fall of 2017 and research items will be classified using the Branch-Mueller and Beesoon Research in LIS Classification scheme. More detailed information including geographic location of the research will also be added to the database going forward.

\section{REFERENCES}

Aharony, N. (2011). Library and information science research areas: A content analysis of articles from the top 10 journals 2007-8. Journal of Librarianship and Information, 44(1), 27-35.

Asselin, M. (2011). Internationalism as leadership in IASL research: Accomplishments and Directions. School libraries Worldwide, 17(2), 13-24.

Branch-Mueller, J., \& Beesoon, G. (2015). School library research rocks: An examination of five years of school library research. In L. H. Das, S. Brand-Gruwel, J. Walhout, \& K. Kok. (Eds.). The School Library Rocks: Proceedings of the 44th International Association of School Librarianship (IASL) conference 2015, Volume II: Research Papers (pp. 22-41). Heerlen, Netherlands: Open Universiteit.

Clyde, L. A. (2006). The basis for evidence-based practice: Evaluating the research evidence. New Library World, 107(5/6), 180-192.

Clyde, L. A. (2005). Supporting information leadership in a culture of change: Researchers in school librarianship. In S. Lee, P. Warning, D. Singh, E. Howe, L. Farmer \& S. Hughes (Eds.). Information Leadership in a Culture of Change: Selected papers from the 34th Annual Conference of the International Association of School Librarianship and the 9th International Forum on Research in School Librarianship. July 8-12, Hong Kong, China. Erie, PA: IASL.

Clyde, L. A. (2004). Evaluating the quality of research publications: A pilot study of school librarianship. Journal of the American Society for Information Science and Technology, 55(13), 1119-1130.

Clyde, L. A. (2003). Research in school librarianship 1991-2000: Australia in an international setting. The Australian Library Journal, 53(2). Retrieved from http://alia.org.au/publishing/ alj/53.2/ full.text/clyde.html

Clyde, L. A. (2002). Developing the knowledge base of the profession: Research in school librarianship. In D. Singh, A. Abdullah, S. Fonseka \& B. de Rozarion (Eds.), School libraries for a knowledge society: Proceedings of the 31st Annual Conference of the International Association of School Librarianship and the Sixth International Forum on Research in School Librarianship (pp. 5975). Seattle, WA: International Association of School Librarianship. 
Clyde, L.A. (2001). Behind the inspiring connections: Research and researchers in school librarianship. A progress report. In Hughes, P. and Selby, L. (Eds). Inspiring Connections: Learning, libraries and literacy, Proceedings of the fifth International Forum on Research in School Librarianship (pp.65-77). Seattle, WA: International Association of School Librarianship.

Clyde, L.A. (1996a). Research articles related to school librarianship, 1990-1995. http://www.iaslslo.org/resbook.html

Clyde, L.A. (Ed.) (1996b). Sustaining the vision: A collection of articles and papers on research in school librarianship. Castle Rock, CO: Hi Willow for the International Association of School Librarianship.

Clyde, L. A., \& Oberg, D. (2004). LIS journals as a source of evidence for evidence-based practice: The case of School Libraries Worldwide. Paper presented at the World Library and Information Congress: 70th IFLA General Conference and Council, Buenos Aires, Argentina, August 22-27. Retrieved from http://archive.ifla.org/IV/ifla70/papers/051e-Clyde_Oberg.pdf

Crase, D., \& Rosate, F. D. (1992). Single versus multiple authorship in professional journal. Journal of Physical Education, 63(7), 28-31.

Donaldson, E. L., \& Emes, C. G. (2000). The challenge for women academics: Reaching a critical mass in teaching, research and service. The Canadian Journal of Higher Education, 30(3), 33-55.

Haycock, K. (1995). Research in teacher-librarianship and the institutionalization of change. School Library Media Quarterly, 23(4), 1-14.

Koufogiannakis, D., Slater, L., \& Crumley, E. (2004). A content analysis of librarianship research. Journal of Information Science, 30(3), 227-239.

Manzari, L. (2013). Library and information science journal prestige as assessed by library and information science faculty. Library Quarterly: Information, Community, Policy, 83(1), 42-60.

Mardis, M. A. (2011). Evidence or evidence based practice? An analysis of IASL Research Forum papers 1998-2009. Evidence Based Library and Information Practice, 6(1), 1-23.

Turcios, M. E., Agarwal, N. K., \& Watkins, L. (2014). How much of library and information science literature qualifies as research? The Journal of Academic Librarianship, 40, 473-479.

Zins, C. (2007). Conceptions of information science. Journal of the American Society for Information Science and Technology, 58(3), 335-350. 